\title{
PENINGKATAN KETERAMPILAN BERBICARA MELALUI MODEL PEMBELAJARAN KOOPERATIF ROUND ROBIN PADA SISWA KELAS IV SD NEGERI BONOSARI TAHUN AJARAN 2020/2021
}

\author{
Sabrina Ayunani ${ }^{1}$, Tri Saptuti Susiani ${ }^{2}$, Ngatman ${ }^{3}$ \\ Universitas Sebelas Maret \\ ayunanisabrina385@gmail.com
}

\section{Article History \\ accepted 1/11/2021}

approved $1 / 12 / 2021$ published 31/12/2021

\begin{abstract}
:
The objectives of the study were: (1) to describe the steps of implementing the Round Robin model, (2) to improve speaking skills through the Round Robin model, and (3) to describe the obstacles and the solutions in implementing the Round Robin model. It was a collaborative classroom action research (CAR) carried out in three cycles. Each cycle consisted of planning, implementation, observation, and reflection. The subjects were teachers and 28 fourth grade students of SD Negeri Bonosari in academic year of 2020/2021. The qualitative data were the application of Round Robin model and quantitative data were the results of student's speaking skill tests in the theme of my neighborhood. Data collection techniques used observation, interviews, and tests. The data validity used triangulation of techniques and triangulation of sources. Data analysis techniques included data reduction, data presentation, and conclusions. The results showed that: (1) the steps in the application of Round Robin model were: (a) grouping students, (b) giving topics/themes, (c) giving worksheets, (d) expressing opinions by students, (e) expressing opinion clockwise; (2) the application of Round Robin model improved student's speaking skills. The percentages of student's mastery learning were $67.91 \%$ in the first cycle, $78.41 \%$ in the second cycle, and $86.53 \%$ in the third cycle; (3) the obstacles that arose in learning at each meeting were: (a) the classroom was small, (b) students preferred friends in group discussions, (c) discussion took times, and (d) the class were less conducive during oral test. The solutions were: (a) the teacher tidied up the tables and benches, (b) the teacher motivated the students not to discriminate friends, (c) the teacher made time limit on each step, (d) the teacher motivated the students to stay calm and focus in the oral test. It concludes that the application of Round Robin model improves student's speaking skills to fourth grade students of SD Negeri Bonosari in academic year of 2020/2021.
\end{abstract}

Keywords: Round Robin model, speaking skills

\begin{abstract}
Abstrak:
Tujuan penelitian ini yaitu: (1) mendeskripsikan langkah penerapan model pembelajaran Round Robin, (2) meningkatkan keterampilan berbicara dengan model pembelajaran Round Robin, serta (3) mendeskripsikan kendala dan solusi dalam penerapan model Round Robin.

Penelitian ini merupakan penelitian tindakan kelas (PTK) kolaboratif yang dilaksanakan dalam tiga siklus, setiap siklus terdiri dari perencanaan, pelaksanaan, observasi, dan refleksi. Subjek penelitian ini adalah guru dan siswa kelas IV SDN Bonosari tahun ajaran 2020/2021 yang berjumlah 28 siswa. Data yang digunakan berupa data kualitatif yaitu penerapan model Round Robin dan data kuantitatif yaitu pada hasil keterampilan berbicara siswa. Teknik pengumpulan data menggunakan observasi, wawancara, dan tes. Validitas data menggunakan triangulasi teknik dan sumber. Analisis data kuantitatif dan kualitatif meliputi reduksi data, penyajian data, dan kesimpulan.

Hasil penelitian menunjukan bahwa: (1) langkah model pembelajaran Round Robin, yaitu: (a) membentuk kelompok 4-6 siswa, (b) pemberian topik, (c) pembagian LKS, (d) salah satu siswa mengutarakan gagasannya, (e) setiap kelompok melanjutkan mengutarakan pendapatnya
\end{abstract}


berputar searah jarum jam; (2) penerapan model Round Robin dapat meningkatkan keterampilan berbicara siswa, yaitu pada siklus I sebesar $67.91 \%$, siklus II meningkat menjadi $74,17 \%$, siklus III sebesar $86,53 \%$; (3) kendala dalam penelitian ini yaitu: (a) ruang kelas yang tidak cukup luas; (b) siswa memilih-milih teman dalam diskusi kelompok; (c) membutuhkan waktu yang cukup lama; (d) kondusi kelas kurang kondusif pada saat tes lisan. Adapun solusinya yaitu; (a) guru mengkondisikan ruang kelas dengan merapikan meja dan bangku; (b) siswa dimotivasi untuk tidak membeda-bedakan teman; (c) guru memberi batasan waktu pada setiap langkah; (d) siswa dimotivasi untuk tetap tenang dan fokus pada saat penliaian lisan.

Simpulan penelitian ini adalah penerapan model Round Robin dapat meningkatkan keterampilan berbicara siswa kelas IV SDN Bonosari tahun ajaran 2020/2021.

Kata Kunci: model Round Robin, keterampilan berbicara siswa tahun ajaran 2020/2021

\section{PENDAHULUAN}

Komunikasi memiliki peranan penting antarmanusia yang dapat menciptakan kedamaian hidup manusia. Peranan komunikasi dapat dirasakan secara langsung maupun tidak langsung oleh pribadi seseorang. Menurut Johnson dalam Hanawi,dkk (2017) empat peranan komunikasi tersebut yaitu: (1) komunikasi membantu perkembangan intelektual dan sosial manusia, (2) terbentuknya identitas dan jati diri dalam dan lewat komunikasi, (3) memahami realitas yang ada di sekeliling, dan (4) mempengaruhi kesehatan mental sebagai akibat kualitas komunikasi. Berbicara menurut Linguis (Tarigan, 2008:3) adalah suatu keterampilan berbahasa yang berkembang pada kehidupan anak, yang hanya didahului oleh keterampilan menyimak. Rosalie Maggio (2006:3) dalam pendahuluan bukunya mengatakan bahwa keterampilan berbicara dengan lancar dan tepat merupakan faktor kunci keberhasilan di tempat kerja dan kebahagiaan hidup.

Kurangnya keterampilan berbicara siswa ditemukan di kelas IV SD Negeri Bonosari. Setelah melakukan observasi pada tanggal 23 November 2019 pada kelas IV peneliti menemukan permasalahan yang berkaitan dengan keterampilan bebicara siswa. Permasalahan keterampilan setiap siswa berbeda, perbedaan tersebut dari segi aspek kebahasaan dan nonkebahasaan. Permasalahan aspek kebahasaan siswa meliputi kesalahan dalam pengucapan dan lafal, penekanan nada dan intonasi, pemilihan kata, serta susunan kalimat dan tata bahasanya. Sedangkan permasalahan aspek nonkebahasaan meliputi kenyaringan, kelancaran, pandangan mata, dan kesediaan untuk menghargai orang lain.

Peningkatan keterampilan berbicara peserta didik perlu disesuaikan dengan masa perkembangan kognitif anak usia sekolah dasar. Pada masa ini tugas perkembangan anak (Desminta, 2016:35) diantaranya mulai belajar bergaul dan bekerja dalam kelompok, menjalankan peranan sosial, serta mencapai kemandirian pribadi. Salah satu struktur pembelajaran kooperatif yang dapat diterapkan untuk meningkatkan keterampilan berbicara adalah model Round Robin. Model pembelajaran kooperatif round robin adalah tipe pembelajaran berkelompok yang jika disebutkan dalam bahasa Indonesia dapat diartikan sebagai menjawab bergiliran menurut Warsono (2013:213). Yusron dalam menerjemahkan buku karangan Barkley menyebutnya round robin sebagai merespon bergiliran. Tipe pembelajaran kooperatif ini dikembangkan oleh Spancer Kagan.

Model round robin dipilih karena sesuai untuk meningkatkan keterampilan berbicara siswa dan mendorong siswa untuk mengungkapkan gagasan dalam kalimatnya sendiri. Semua siswa dalam kelompok memiliki kesempatan yang sama untuk berpendapat. Model pembelajaran ini dapat membuat siswa mengetahui pendapat teman yang lain sehingga mampu menambah perbendaharaan kata siswa. 
Berdasarkan uraian di atas, dapat dirumuskan masalah sebagai berikut: (1) Bagaimana langkah penggunaan model pembelajaran kooperatif Round Robin untuk meningkatkan keterampilan berbicara pada siswa kelas IV SD Negeri Bonosari tahun ajaran 2020/2021? (2) Apakah penggunaan model pembelajaran kooperatif Round robin dapat menungkatkan keterampilan berbicara pada siswa kelas IV SD Negeri Bonosari tahun ajaran 2020/2021?(3) Bagaimana kendala dan solusi penggunaan model pembelajaran kooperatif round robin untuk meningkatkan keterampilan berbicara pada siswa kelas IV SD Negeri Bonosari tahun ajaran 2020/2021?

Tujuan penelitian ini yaitu: (1) Mendeskripsikan langkah penggunaan model pembelajaran kooperatif Round Robin untuk meningkatkan keterampilan berbicara pada siswa kelas IV SD Negeri Bonosari tahun ajaran 2020/2021 (2) Meningkatkan keterampilan berbicara melalui model pembelajaran kooperatif round robin pada siswa kelas IV SD Negeri Bonosari tahun ajaran 2020/2021 (3) Mendeskripsikan kendala dan solusi penerapan model pembelajaran kooperatif Round Robin untuk meningkatkan keterampilan berbicara pada siswa kelas IV SD Negeri Bonosari tahun ajaran 2020/2021.

\section{METODE}

Penelitian ini dilaksanakan di SDN Bonosari yang berlangsung dari bulan November 2019 sampai Juni 2021. Subjek penelitian ini adalah guru dan siswa kelas IV yang berjumlah 28 siswa yang terdiri dari 17 siswa laki-laki 11 siswa perempuan.

Penelitian tindakan kelas ini dilakukan secara kolaboratif. Data yang digunakan berupa data kualitatif yaitu penerapan model pembelajaran Round Robin dan data kuantitatif yaitu pada tes hasil belajar siswa dalam mata pelajaran matematika. Teknik pengumpulan data menggunakan observasi, wawancara, dan tes. Validitas data menggunakan triangulasi teknik dan sumber. Teknik analisis data meliputi reduksi data, penyajian data, dan kesimpulan.

Indikator kinerja penelitian ini adalah penerapan model pembelajaran Round Robin dan hasil peningkatan keterampilan berbicara siswa $(\mathrm{KKM}=75)$ ditargetkan mencapai $85 \%$. Adapun prosedur penelitian ini menggunakan model penelitian tindakan kelas yang terdiri dari empat tahapan, yaitu (1) perencanaan, (2) pelaksanaan, (3) observasi, (4) refleksi.

\section{HASIL DAN PEMBAHASAN}

Penelitian ini dilaksanakan tiga siklus dengan lima kali pertemuan. Langkahlangkah model Round Robin yang sudah dilaksanakan pada III siklus yaitu: (a) mengelompokan siswa, (b) pemberian tema, (c) pembagian LKS, (d) masing-masing siswa mengutarakan pendapatnya, (e) setiap kelompok melanjutkan presentasi searah jarum jam. Langkah pembelajaran tersebut mengacu pada langkah-langkah yang dikemukakan oleh Barkley (2012: 163-164), dan Warsono (2013: 213-214).

Hasil observasi penerapan model round robin mengalami peningkatan pada setiap siklusnya hingga mencapai kinerja penelitian yang ditargetkan sebesar $85 \%$.

Tabel 1 Analisis Hasil Pengamatan Penerapan Model Round Robin Siklus I, II, dan III

Sumber Data Siklus




\begin{tabular}{ccccc}
\hline & & I & II & III \\
\hline Guru & Rata-rata & 67,91 & 73,54 & 91,25 \\
\hline Siswa & Rata-rata & 63,54 & 74,79 & 89,17 \\
\hline
\end{tabular}

Berdasarkan tabel 1 dapat diketahui bahwa persentase penerapan langkah model Round Robin pada setiap siklus mengalami peningkatan.

Tabel 2 Analisis Presentasi Peningkatan Keterampilan Berbicara melalui Model Round Robin Siklus I, II, dan III

\begin{tabular}{ccccc}
\hline No & Siklus & \multicolumn{3}{c}{ Tuntas (\%) } \\
\cline { 3 - 5 } & & Pertemuan I & Pertemuan II & Rata-rata \\
\hline $\mathbf{1}$ & I & 53,45 & 54,80 & 54,13 \\
$\mathbf{2}$ & II & 73,54 & 74,79 & 74.17 \\
$\mathbf{3}$ & III & 86,53 & - & 86,53 \\
\hline
\end{tabular}

Berdasarkan tabel 2 dapat dilihat bahwa hasil keterampilan berbicara meningkat mulai dari siklus I sampai dengan siklus III. Dengan demikian penerapan model Round Robin dapat meningkatkan keterampilan berbicara siswa yang dilihat dari persentase siswa yang memenuhi ketercapaian target dari siklus I - III.

Kendala yang muncul dalam pembelajaran pada setiap pertemuan yaitu yaitu: (1) ruang kelas yang tidak cukup luas; (2) siswa memilih-milih teman dalam diskusi antarkelompok; (3) membutuhkan waktu yang cukup lama; (4). kondisi kelas kurang kondusif pada saat tes lisan. Adapun solusinya yaitu: (1) guru mengondisikan ruang kelas dengan merapikan meja dan bangku; (2) siswa dimotivasi untuk tidak membedabedakan teman; (3) guru memberi batasan waktu pada setiap langkah untuk menyingkat waktu; (4) siswa dimotivasi untuk tetap tenang dan fokus pada saat penilaian tes lisan, siswa di arahkan untuk mengingat kembali materi yang sudah dipelajari.

\section{SIMPULAN DAN SARAN}

Berdasarkan rumusan masalah, hasil penelitian, dan pembahasan dalam penelitian ini, dapat diambil kesimpulan sebagai berikut: (1) Model Round robin dalam meningkatkan keterampilan berbicara pada tema daerah tempat tinggalku melalui lima langkah yaitu: (a)mengelompokan siswa, (b) pemberian topik atau tema, (c) pemberian LKS, (d) siswa mengutarakan pendapatnya, (e) setiap kelompok mengutarakan pendapatnya searah jarum jam. (2) Penerapan model round robin dapat meningkatkan keterampilan berbicara pada tema daerah tempat tinggalku siswa kelas IV SD Negeri Bonosari Tahun Ajaran 2020/2021. Dapat dilihat dari hasil persentase peningkatan keterampilan berbicara secara keseluruhan pada siklus I yaitu $67.91 \%$, siklus II menjadi $78,41 \%$ dan siklus III meningkat menjadi $86,53 \%$.(3) Kendala penerapan model Round Robin untuk meningkatkan keterampilan berbicara siswa kelas IV SDN Bonosari tahun ajaran 2020/2021 yaitu: (a) ruang kelas yang tidak cukup luas; (b) siswa memilih-milih teman dalam diskusi antarkelompok; (3) membutuhkan waktu yang cukup lama; (c). kondisi kelas kurang kondusif pada saat tes lisan. Adapun solusi dari kendala-kendala tersebut, yaitu: (a) guru mengondisikan ruang kelas dengan merapikan meja dan bangku; (b) siswa dimotivasi untuk tidak membeda-bedakan teman; (c) guru memberi batasan waktu pada setiap langkah untuk menyingkat waktu; (d) siswa dimotivasi untuk tetap tenang dan fokus pada saat penilaian tes lisan, siswa di arahkan untuk mengingat kembali materi yang sudah dipelajari. 
Berkaitan dengan hasil penelitian yang telah dicapai, peneliti mengajukan saran sebagai berikut: (1) Sebaiknya siswa memiliki semangat dan motivasi yang tinggi untuk belajar mempraketekkan secara langsung menyampaikan pendapat, (2) guru lebih kreatif lagi dalam mengajar dengan menggunakan model-model yang bervariasi dan menyenangkan dan juga disesuaikan dengan materi dan karakteristik siswa pemahaman siswa lebih terkonsep dan sulit dilupakan siswa.

\section{DAFTAR PUSTAKA}

Barkley, E.E., Cross, K. P., \& Major, C. H. (2012). Collaborative Learning Techniques. Jakarta: Nusa Media.

Desminta. (2016). Psikologi Perkembangan Peserta Didik. Bandung: PT Remaja Rosdakarya.

Hanawi,. Ummul, Q,. \& Indah, R. (2017). Keterampilan Berbicara Sebagai Suatu Keterampilan Berbahasa. Jakarta: Uhamka Press.

Maggio, R. (2006). Sukses Berbicara dengan Siapa Saja. Jakarta: PT Gramedia Pustaka Utama.

Tarigan, H. G. (2015). Berbicara sebagai Suatu Keterampilan Berbahasa. Bandung: Angkasa.

Warsono, \& Hariyanto. (2013). Pembelajaran Aktif: Teori dan Assesmen. Bandung: PT Remaja Rosdakarya 